\title{
THE POSSIBILITY OF ULTRAVIOLET ENCELADUS' OBSERVATIONS FROM STRATOSPHERIC BALLOONS
}

\author{
Jan Kotlarz*, Natalia Zalewska*,** \\ *European Astrobiology Network Association \\ ${ }^{* *}$ Center of Space Technologies, Institute of Aviation, Al. Krakowska 110/112, 02-256 Warsaw \\ jan.kotlarz@ilot.edu.pl;natalia.zalewska@ilot.edu.pl
}

\begin{abstract}
Stratospheric balloons are very important sources for space and terrestrial observation experiments in many disciplines. Instruments developed for astrophysical measurements are usually reusable. It is also possible to observe both hemispheres including observations from the polar and equatorial regions for thirty days or even longer. On the other hand the UV atmospheric transmittance window was used for the astrophysical observations less often than visible optical bands. At the end of the 2017 there are a few scientific groups working on near-UV or UV spectrographs and cameras for balloon flights.

In this paper we are discussing the possibility of ultraviolet measurement of Enceladus, an icy Saturnian moon, surface reflectance between 200 and $400 \mathrm{~nm}$ from the 20-50 km altitudes. At visible and near infrared optical channels Enceladus' reflectance is very high (near 1.0). This value is consistent with a surface composed of water ice, however at some ultraviolet wavelengths Enceladus reflectance is lower than it would be expected for this type of surface. The scientific research done in the last decade was focused on $\mathrm{H}_{2} \mathrm{O}, \mathrm{NH}_{3}$, and tholin particles detection on the Enceladus' surface as a reason of low UV reflectance phenomenon. Continuous observation of Enceladus' UV reflectance variability from stratospheric balloons may be interesting and may give us the proof of the presence of biomarkers or/and tholin particles.
\end{abstract}

Keywords: stratospheric balloons, Enceladus, ultraviolet, water ice, tholin.

\section{INTRODUCTION}

Modern large telescope and spectrograph systems may be used to acquire sensitive spectra of the plumes of Enceladus and Europa and observe their bright surfaces [1]. There are two main scientific goals during this type of observations: a) the separation small celestial objects from Jupiter and Saturn and b) Earth's atmosphere absorption in ultraviolet (UV) and partially in infrared (IR) wavelengths $[2,3]$. This is the main reason why the UV observations are realized from the orbital level including the astrophysical objects in the outer Solar System [4]. On the other hand there is 
possibility to use stratospheric UAV's or balloons dedicated for UV astronomy. Autonomous or partially autonomous multisensor platform development for stratospheric altitudes was frequently implemented into different types of projects [5]. Scientific groups in Europe [6] and India [7, 8] actually are preparing experiments dedicated to this hard to observe from the Earth's ground part of the electromagnetic spectrum.

\subsection{Stratospheric balloon UV experiments in astronomy}

The ultraviolet atmospheric window has been explored through balloons for astronomy in general for Sun measurements. The 12 inch Stratoscope flew multiple times in 1950's [9]. The SUNRISE solar observatory on the stratospheric balloon contained $1 \mathrm{~m}$ aperture Gregory telescope with UV filter [10]. Five 2-hours flights were dedicated for galaxies or clusters of galaxies in Coma, Virgo and Cancer constellations [11] measurements by $40 \mathrm{~cm}$ telescope in $200 \mathrm{~nm}$ UV band. Also star-formation regions were observed in the same band during long-time flights [12].

All of those experiments successfully gathered astrophysical data. In every case experiment was dedicated for long-time duration flight. Also today scientific teams are preparing for balloon-borne telescope experiments. I.e. Indian Institute of Astrophysics is developing a pointing and stabilization balloon platform [7] and a compact UV Imager that can be flown on a small CubeSat or a balloon platform [8]. This equipment will enable to proceed stable observations of regions of interest, especially astronomical objects in the Solar System (planets, satellites, comets etc.).

Successful pointing and stabilization hardware and software is particular part of each stratospheric balloon project in the field of astronomy [13]. In the case of UV part of the spectrum it is very important to prepare observations near the local zenith where Earth's atmospheric transmittance is above the necessary minimum. This condition significantly limits potential UV observations area on the sky.

\subsection{UV observations of the Enceladus' surface}

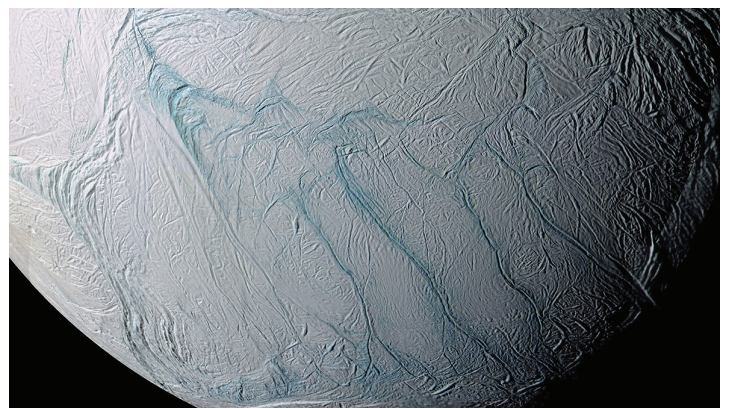

Fig. 1. Tiger Stripes near Enceladus' south pole imaged by Cassini visual mapping spectrometer developed by NASA's Jet Propulsion Laboratory [18].

Most of the UV Enceladus observations in 2016 and 2017 were used to measure variability of water vapor in plumes near its south pole [14, $15,16,17]$ and detecting specific micron-sized particles including water ice, $\mathrm{CO}_{2}, \mathrm{NH}_{4}, \mathrm{CH}_{4}$ originated from four terrain's fractures named Tiger Stripes [18] (see Figure 1).

One of the most interesting things in Enceladus' surface reflectance spectrum is that visible and near infrared reflectance is very high (near 1.0), however at middle and far UV bands Enceladus' reflectance is lower than it would be expected for pure water-ice type of surface. Some investigations suggests that it may be indication of tholin particles presence. Tholins are multiplechain polymers formed from simple organic compounds such as water $\left(\mathrm{H}_{2} \mathrm{O}\right)$, methane $\left(\mathrm{CH}_{4}\right)$, ammonia $\left(\mathrm{NH}_{3}\right)$ and hydrogen $\left(\mathrm{H}_{2}\right)$ [19]. Ultraviolet radiation or electrical discharges are needed to create those polymers. The products of these reactions are ethylene, acetylenes, cyanhydrides and also nitrogen widely distributed on the surfaces of ice bodies. Their color are from reddish pink to dark brown. A wide spectrum of these compounds has been discovered on the moons of Jupiter, Saturn, Neptune 
and on transneptoon objects, among others on the dwarf planet - Pluto. Recently tholins have been discovered on comets and ice asteroids.

Tholins on Enceladus can be formed i.e. in the process of irradiation of ice containing methane clathates [20]. Additionaly methane was confirmed as a component of the plumes on Enceladus [21]. The variability of Enceladus' UV reflectance continuous monitoring may help to collect data important for this scientific topic. Stratospheric balloons spectrograph or maybe telescopes observations will be important platforms in this area in the next few decades [7].

\section{METHODOLOGY}

There is a set of boundary parameters that must be met by experiment to observe celestial object in UV band. We assumed that it is possible to observe only those objects on the hemisphere where atmospheric transmittance in UV is higher than 0.2 [12]. This transmittance parameter depends on the

a. flight altitude $h$,

b. zenith angle $\varphi$ of celestial object during experiment.

To estimate effective atmospheric transmittance $T_{e f f}(h, \varphi)$ in the Enceladus' area on the hemisphere we calculated:

a. zenith transmittance $T_{\text {zenith }}(h)=T_{\text {eff }}\left(h, 0^{\circ}\right)$ for altitudes $20 \mathrm{~km}, 30 \mathrm{~km}, 40 \mathrm{~km}$ and $50 \mathrm{~km}$,

b. effective atmospheric transmittance as a function of $T_{\text {zenith }}$ and zenith angle $\varphi$,

c. relation between Enceladus' zenith angle $\varphi$, balloons latitude $B L$ and Enceladus' declination $\delta$,

d. balloons position variability during theoretical 18-hours flight with starting point near Krotoszyn, central Poland.

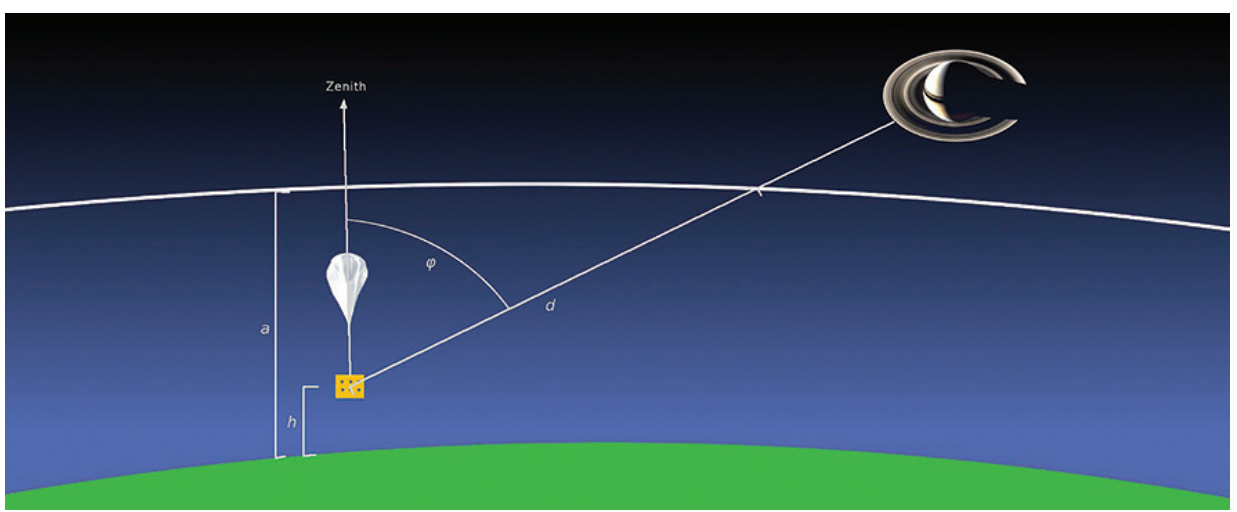

Fig. 2. Atmosphere optical depth $d$ as a function of balloon's altitude $h$, width of the atmosphere $a$ and zenith angle $\varphi$ (see: eq. 2) [own work].

\subsection{UV atmospheric transmittance at zenith as a function of balloon altitude}

Using Huffman model of UV atmosphere radiation for zenith angle intervals from $0^{\circ}-30^{\circ}$ up to $0^{\circ}-75^{\circ}[22]$ and UV atmospheric transmittance model based on pre-flight calibrations in Donas et al. experiment [12] we may approximate ultraviolet transmittance of the atmosphere near zenith as a function of balloon altitude. In our investigation we estimated 13 UV bands: $150 \mathrm{~nm}, 175 \mathrm{~nm}, 190$ $\mathrm{nm}, 200 \mathrm{~nm}, 210 \mathrm{~nm}, 225 \mathrm{~nm}, 250 \mathrm{~nm}, 275 \mathrm{~nm}, 300 \mathrm{~nm}, 325 \mathrm{~nm}, 350 \mathrm{~nm}, 375 \mathrm{~nm}$ and $400 \mathrm{~nm}$. 


\subsection{UV atmospheric transmittance as a function of zenith transmittance and object's zenith angle}

We assumed that atmosphere air mass between balloon and object is linear function of the distance $\mathrm{d}$ between balloon and object in its part inside Earth atmosphere. Inputs in our air mass model are: Earth radius $r=6371 \mathrm{~km}$, balloon altitude over ground $h$, total thickness of the atmosphere $a=100 \mathrm{~km}$ and finally azimuth angle between zenith direction and object direction $\varphi$. Distance $d$ between balloon and the top of the atmosphere in the direction of celestial object may be calculated simply using law of sines:

$$
\frac{r+a}{\sin (\pi-\phi)}=\frac{r+h}{\sin (\beta)}=\frac{d}{\sin (\alpha)}
$$

where:

$a$ is an angle between lines a) passing through the center of the Earth and balloon and b) the center of the Earth and celestial object

$\beta=\varphi-a$

The final expression of $\mathrm{d}$ will reduce to:

$$
d=\frac{r+a}{\sin \varphi} \sin \left(\varphi-\arcsin \left(\frac{(r+h) \sin \varphi}{a+r}\right)\right)
$$

Atmosphere transmittance in UV given in the azimuth angle will reduce by factor $d /(a-h)$ :

$$
T_{\text {eff }}=T_{\text {zenith }} \frac{a-h}{d}
$$

\subsection{Enceladus' zenith angle}

Enceladus is a satellite of the Saturn. An apsis of its orbit is $239160 \mathrm{~km}$ (=0.0160 AU). The minimum distance between Earth and Saturn is 8,1783 AU. This means that maximum theoretical Enceladus' orbital movement around Saturn on the hemisphere is $0.0224^{\circ}$. Saturn, as all of the planets in Solar System is moving near ecliptic. Maximum angle between ecliptic and Saturn is $2.4850^{\circ}$ resulting Enceladus' declination between $\delta_{\min }=-\left(23.4500^{\circ}+2.4850^{\circ}+0.0224^{\circ}\right)=-25.9574^{\circ}$ and $\delta_{\max }=+\left(23.4500^{\circ}+2.4850^{\circ}+0.0224^{\circ}\right)=25.9574^{\circ}$. Minimum and maximum zenith angle during one day:

$$
B L-\delta<\varphi<180^{\circ}-B L-\delta
$$

We can see that Enceladus' zenith angle depends on balloons latitude, Enceladus' declination variability and rotational movement of the Earth.

\subsection{Balloon latitude and longitude variability during flight}

$B L$ depends on the balloon starting point. $B L$ variability depends on the local winds velocities and directions in stratosphere and duration of the flight. During 18-hours flight balloon may change its latitude in a significant way. For this variability estimation we used wind velocity and direction data $[23,24]$ for the general structured air masses in stratosphere. Based on this data for each of four altitudes: $20 \mathrm{~km}, 30 \mathrm{~km}, 40 \mathrm{~km}$ and $50 \mathrm{~km}$ we prepared 100 numerical simulations of the balloon flight with simulation parameters: 
- time step (time when wind direction and velocity weren't change) $\Delta \mathrm{t}=1 \mathrm{~min}$,

- wind direction standard deviation $\sigma_{\mathrm{V}}=180^{\circ}$,

- flight duration $T=18 \mathrm{~h}$.

After every simulation we calculated average and standard deviation of the position of the balloon during whole flight.

\section{RESULTS}

\subsection{Earth's atmosphere transmittance in ultraviolet}

Estimated transmittance in zenith direction $T_{\text {zenith }}$ depends from balloon's altitude (Figure 3). Effective transmittance $T_{\text {eff }}$ depends from zenith angle $\varphi$ (Figure 4).

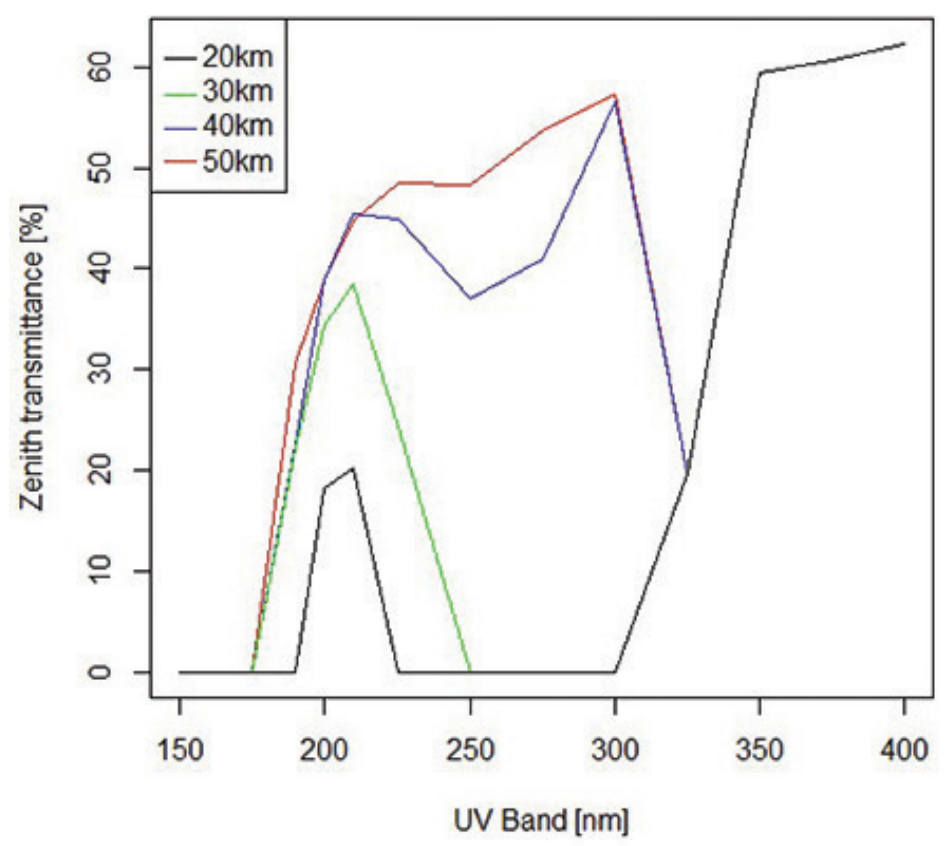

Fig. 3. UV transmittance of the Earth's atmosphere near zenith direction as a function of balloons altitude [own work]. 

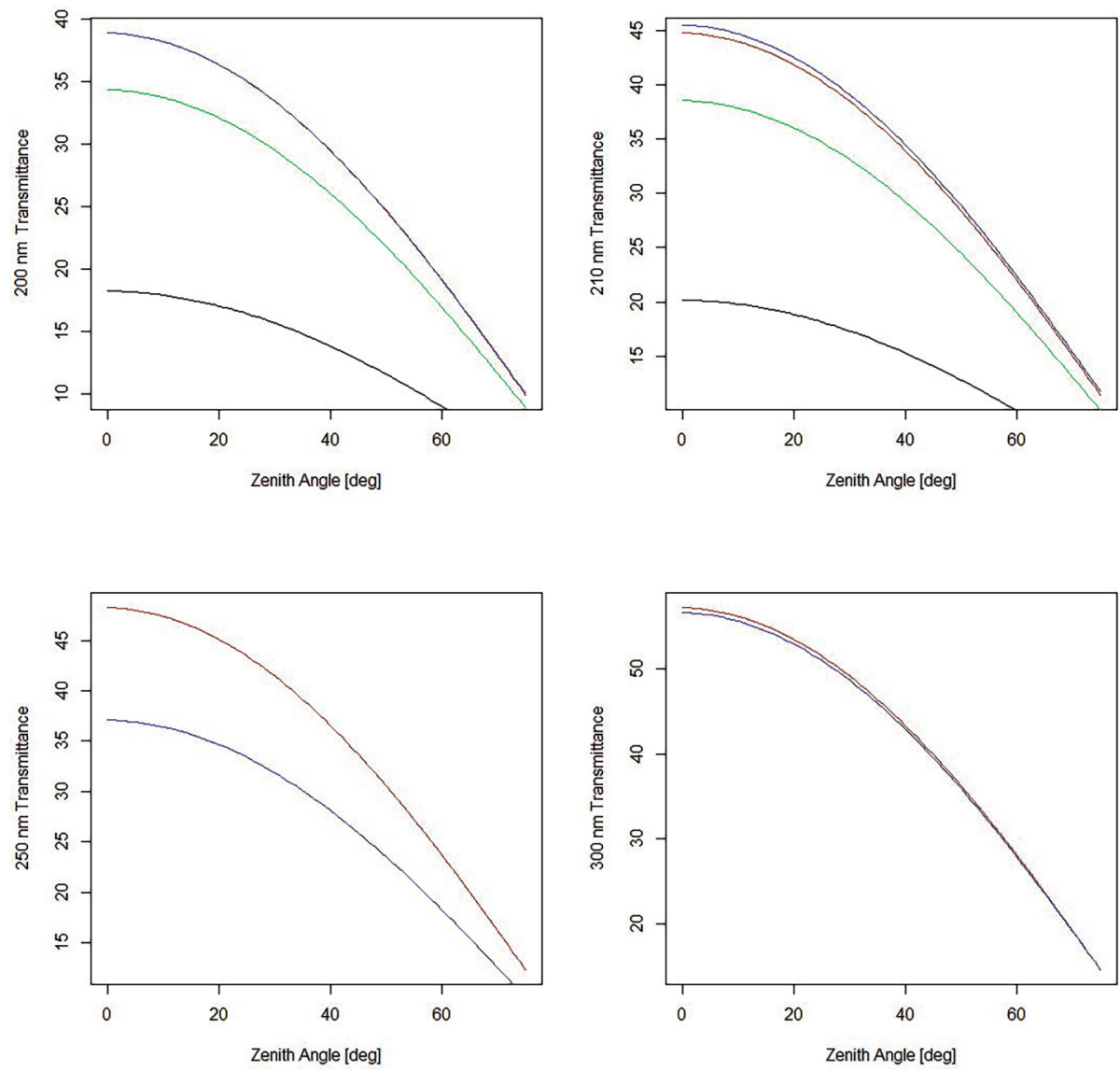

Fig. 4. UV bands ( $200 \mathrm{~nm}, 210 \mathrm{~nm}, 250 \mathrm{~nm}$ and $300 \mathrm{~nm}$ ) effective atmospheric transmittance $T_{\text {eff }}$ as a function of zenith angle on four balloon altitudes: $20 \mathrm{~km}$ (black), $30 \mathrm{~km}$ (green), $40 \mathrm{~km}$ (blue) and $50 \mathrm{~km}$ (red) [own work].

\subsection{Balloons position variability}

The result of the balloon position variability in numerical simulation is presented on the Figure 5 and Table 1.

Tab. 1. Stratospheric balloon's longitude and latitude variability during 18 hours flight on four altitudes: $20 \mathrm{~km}, 30 \mathrm{~km}, 40 \mathrm{~km}$ and $50 \mathrm{~km}$ with starting point near Krotoszyn, Poland $\left(51.70^{\circ} \mathrm{N}\right.$, $17.44^{\circ} \mathrm{E}$ ) [own work]

\begin{tabular}{|c|c|c|}
\hline Balloon altitude $[\mathbf{k m}]$ & Longitude $\lambda[\mathbf{d e g}]$ & Latitude $\varphi[\mathbf{d e g}]$ \\
\hline 20 & $16.02( \pm 1.30)$ & $51.64( \pm 0.97)$ \\
\hline 30 & $20.32( \pm 1.93)$ & $51.69( \pm 0.99)$ \\
\hline 40 & $22.48( \pm 3.15)$ & $51.75( \pm 1.03)$ \\
\hline 50 & $24.53( \pm 4.26)$ & $51.67( \pm 1.22)$ \\
\hline
\end{tabular}



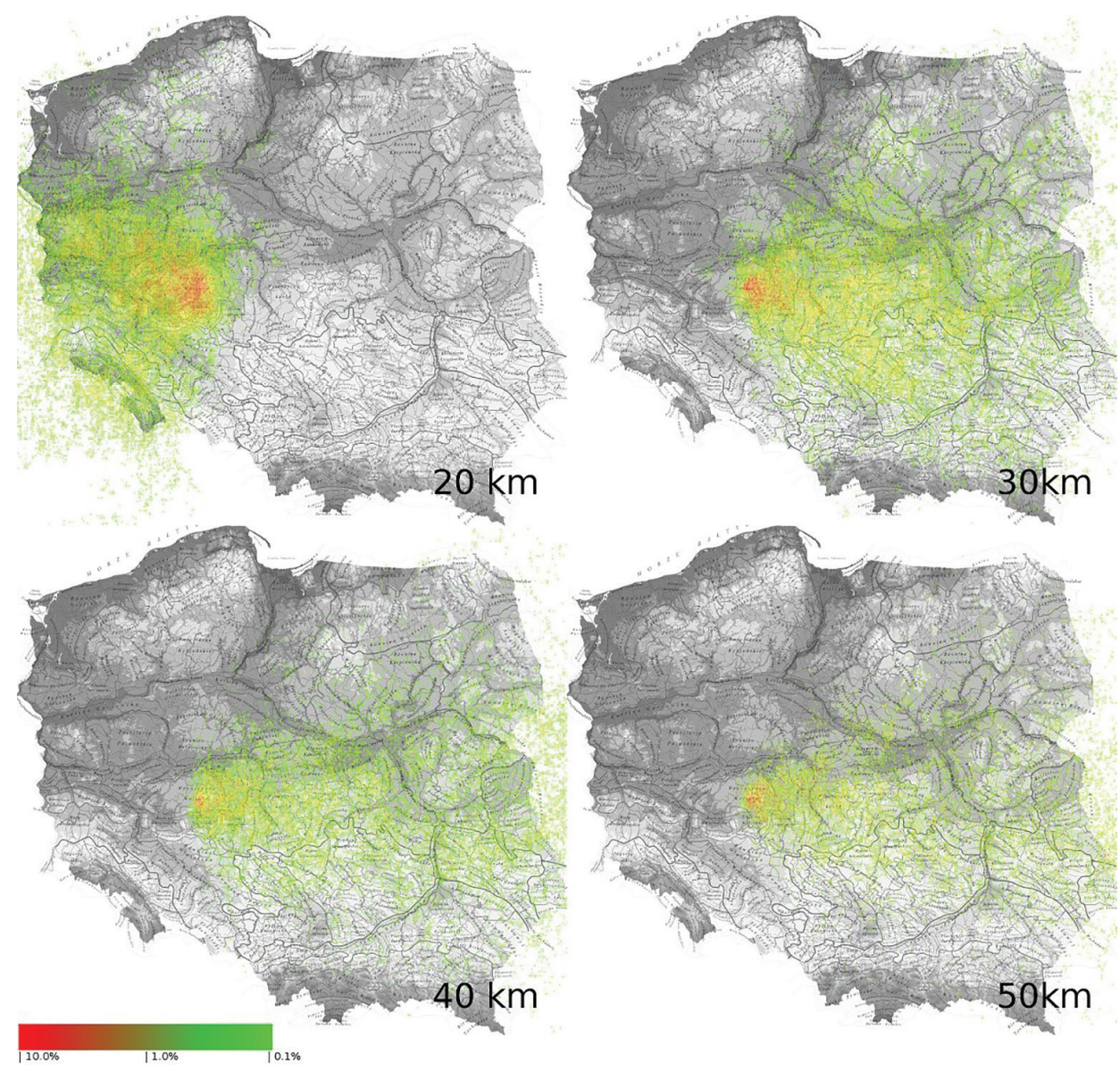

Fig. 5. Stratospheric balloon position density during 18 hours flight on four altitudes: $20 \mathrm{~km}, 30 \mathrm{~km}, 40 \mathrm{~km}$ and $50 \mathrm{~km}$ with starting point near Krotoszyn, Poland $\left(51.70^{\circ} \mathrm{N}\right.$, $17.44^{\circ} \mathrm{E}$ ) [own work].

\subsection{Enceladus' declination and balloon latitude boundary conditions}

We assumed necessary condition for Enceladus observation: effective transmittance $T_{\text {eff }}$ should be equal or greater than threshold selected: 0.2 value regarding to Donas et al. experiment [12].

$$
T_{\text {eff }}=T_{\text {zenith }} \frac{a-h}{d} \geq 0.2
$$

$d$ may be calculated using equation (2). As the result for every altitude $h$ we calculated $\varphi$ range where $T_{\text {eff }} \geq 0.2$ (see: Table 2). 
Tab. 2. Maximum zenith angle for observations in five UV bands $(200 \mathrm{~nm}, 250 \mathrm{~nm}, 300 \mathrm{~nm}, 350 \mathrm{~nm}$, $400 \mathrm{~nm})$ calculated for four stratospheric balloon altitudes $(20-50 \mathrm{~km})$ with starting point near Krotoszyn, central Poland [own work]

\begin{tabular}{|c|c|c|c|c|c|}
\hline \multirow{2}{*}{$\begin{array}{c}\text { Balloon } \\
\text { altitude }[\mathbf{k m}]\end{array}$} & \multicolumn{5}{|c|}{$\boldsymbol{\varphi}$ maximum for UV band } \\
\cline { 2 - 6 } & $200 \mathrm{~nm}$ & $250 \mathrm{~nm}$ & $300 \mathrm{~nm}$ & $350 \mathrm{~nm}$ & $400 \mathrm{~nm}$ \\
\hline $\mathbf{2 0}$ & - & - & - & 71.33 & 72.31 \\
\hline $\mathbf{3 0}$ & 54.79 & - & - & 71.45 & 72.45 \\
\hline $\mathbf{4 0}$ & 59.47 & 57.75 & 70.02 & 72.01 & 72.92 \\
\hline $\mathbf{5 0}$ & 59.49 & 66.00 & 70.13 & 72.12 & 73.40 \\
\hline
\end{tabular}

\section{DISCUSSION}

For 18-hours missions described in $3.299 .5 \% B L$ values were $\left(\widehat{B L} \pm 3 \sigma_{B L}\right)$ :

- for altitude $20 \mathrm{~km}: 48.73^{\circ}-54.55^{\circ}$

- for altitude $30 \mathrm{~km}: 48.72^{\circ}-54.66^{\circ}$

- for altitude $40 \mathrm{~km}: 48.66^{\circ}-54.84^{\circ}$

- for altitude $50 \mathrm{~km}: 47.98^{\circ}-55.30^{\circ}$.

Enceladus' declination may vary from $-25.96^{\circ}$ to $+25.96^{\circ}$. We can set boundary condition for observation possibility during whole 18-hours flights:

$$
B L \leq \varphi_{\max }+\delta
$$

The equation 6 should be met for the time of observation during flight. It is clear that this boundary condition should be met to maximum $B L$ for each altitude. Now we calculated minimum Enceladus' declination for observations for five UV bands (see: Table 3).

Tab. 3. Minimum Enceladus' declination for observations in five UV bands $(200 \mathrm{~nm}, 250 \mathrm{~nm}, 300 \mathrm{~nm}$, $350 \mathrm{~nm}, 400 \mathrm{~nm}$ ) from four altitudes $(20-50 \mathrm{~km})$ [own work]

\begin{tabular}{|c|c|c|c|c|c|}
\hline \multirow{2}{*}{$\begin{array}{c}\text { Balloon } \\
\text { altitude }[\mathbf{k m}]\end{array}$} & \multicolumn{5}{|c|}{ Enceladus' minimum declination for observations in UV band } \\
\cline { 2 - 6 } & $200 \mathrm{~nm}$ & $250 \mathrm{~nm}$ & $300 \mathrm{~nm}$ & $350 \mathrm{~nm}$ & $400 \mathrm{~nm}$ \\
\hline $\mathbf{2 0}$ & $\begin{array}{c}\text { Observations } \\
\text { not possible }\end{array}$ & $\begin{array}{c}\text { Observations } \\
\text { not possible }\end{array}$ & $\begin{array}{c}\text { Observations } \\
\text { not possible }\end{array}$ & $-16,78$ & $-17,76$ \\
\hline $\mathbf{3 0}$ & $-0,13$ & $\begin{array}{c}\text { Observations } \\
\text { not possible }\end{array}$ & $\begin{array}{c}\text { Observations } \\
\text { not possible }\end{array}$ & $-16,79$ & $-17,79$ \\
\hline $\mathbf{4 0}$ & $-4,63$ & $-2,91$ & $-15,18$ & $-17,17$ & $-18,08$ \\
\hline $\mathbf{5 0}$ & $-4,19$ & $-10,70$ & $-14,83$ & $-16,82$ & $-18,10$ \\
\hline
\end{tabular}

For an altitude $20 \mathrm{~km}$ only UV bands over $350 \mathrm{~nm}$ are useful for the observations. For the longterm planning we may assume that near $75 \%$ time will met boundary conditions for the observations from Poland. The main topic for this UV bands are monitoring water-ice amount on the Enceladus' surface $[25,26]$. We can not expect biomarkers or tholins detection in this part of UV spectrum. 
For an altitude $30 \mathrm{~km}$ we have additionally $200 \mathrm{~nm}$ band available for over $50 \%$ long-term time. This UV band applied previously for stratospheric balloon observations [12] is adequate for $\mathrm{H}_{2} \mathrm{O}$, $\mathrm{NH}_{3}$ and a tholin particles detection [25]. We may suppose that analysis of water-ice and tholin particles variability on Enceladus' surface are possible using data collected on this altitude.

For the altitude $40-50 \mathrm{~km}$ we have the same situation as for the $30 \mathrm{~km}$ altitude experiment. Observations in $200 \mathrm{~nm}$ band are possible during 55\% of time and in $350 \mathrm{~nm}-400 \mathrm{~nm}$ bands in about $75 \%$ of time. Additionally these altitudes are adequate for the monitoring in $250-300 \mathrm{~nm}$ bands. This bands may be useful for dust [27] and hydrogen peroxide particles monitoring [28].

We should be careful with these results. The assumption of minimum atmospheric transmittance $\sim 0.2$ may be too bold, but even if the minimum transmittance will increase during future experiments, we can say that the Enceladus' observations in ultraviolet bands from Europe are possible on the minimum altitude $40 \mathrm{~km}$. Equation 6 suggest that the best starting points for Enceladus' observations are near the Earth's equator. Proposed by scientific group in India experiment $[7,8]$ with starting point altitude around $10^{\circ}$ will have better conditions for UV observations than theoretical experiment with starting point in Central Europe presented in this paper as the numerical simulation.

\section{CONCLUSIONS}

Enceladus' UV reflectance variability may be measure during stratospheric balloons flights over Poland in two main bands: $200 \mathrm{~nm}$ and $350-400 \mathrm{~nm}$ on the altitudes $20-30 \mathrm{~km}$ in $50-75 \% \mathrm{En}$ celadus' declination values. On the altitudes over $40 \mathrm{~km}$ it is possible to measure reflectance variability in all UV spectrum between 200 and $400 \mathrm{~nm}$. These results were calculated for atmosphere transmittance $T_{\text {eff }}>0.2$ boundary condition. This result showed that from the lower stratosphere $(<30 \mathrm{~km})$ we may measure reflectance of the pure-ice surface. $\mathrm{H}_{2} \mathrm{O}, \mathrm{NH}_{3}$ and tholin particles detection may be possible from the altitudes over $30 \mathrm{~km}$. Additionally dust reflectance may be measured from the higher stratosphere $(>40 \mathrm{~km})$.

In general starting points with low latitudes (near equator) are better for this type of experiments, but stratospheric flights over European latitudes over $30 \mathrm{~km}$ also offer sufficient conditions to conduct experiments.

\section{REFERENCES}

[1] Judge P., 2017, "A novel strategy to seek biosignatures at Enceladus and Europa”, Astrobiology, 17(9), 852-861.

[2] Vollmer M., Klaus-Peter, M. Á., 2017, Infrared thermal imaging: fundamentals, research and applications, John Wiley \& Sons.

[3] Carn S. A., Krotkov, N. A., 2016, Volcanic Ash, Elsevier, Chap. 12.

[4] Becker T. M., Retherford K. D., Roth L., McGrath M. A., Saur J., Hendrix A. R., Raut U., 2016, "Far-UV Spectral and Spatial Analysis from HST Observations of Europa", AGU Fall Meeting Abstracts.

[5] Czapski P., Dorosz K., Kacprzak M., Korniluk T., Kotlarz J., Mazur A., Rotchimmel K., 2016, "Pozyskiwanie i przetwarzanie danych lotniczych i satelitarnych przez zespół badawczy Zakładu Teledetekcji Instytutu Lotnictwa" (Acquisition and processing of aerial and satellite data by a research team of the Remote Sensing Department in Institute of Aviation), Przegląd Geodezyjny, 88(3), 4-9. 
[6] Romualdez L. J., Benton S. J., Clark P., Damaren C. J., Eifler T., Fraisse A. A., Lipton L., 2016, "The design and development of a high-resolution visible-to-near-UV telescope for balloon-borne astronomy: SuperBIT”. arXiv preprint arXiv:1608.02502.

[7] Sreejith A. G., Mathew J., Sarpotdar M., Nirmal K., Ambily S., Prakash A., Murthy J., 2016, "Balloon UV experiments for astronomical and atmospheric observations", arXiv preprint arXiv:1608.06385.

[8] Ambily S., Mathew J., Sarpotdar M., Sreejith A. G., Nirmal K., Prakash A., Murthy J., 2016, "Near UV imager with an MCP-based photon counting detector", Space Telescopes and Instrumentation 2016: Ultraviolet to Gamma Ray, Vol. 9905, p. 990539, International Society for Optics and Photonics.

[9] Danielson R. E., 1961, “The Structure of Sunspot Penumbras”, The Astrophysical Journal, 134, p. 275.

[10] Solanki S. K., Barthol P., Danilovic S., Feller A., Gandorfer A., Hirzberger J., del Toro Iniesta J. C., 2010, "SUNRISE: instrument, mission, data, and first results", The Astrophysical Journal Letters, 723(2), L127.

[11] Milliard B., Donas J., Laget M., 1991, "A 40-cm UV (2000 Å) balloon-borne imaging telescope: results and current work", Advances in Space Research, 11(11), 135-138.

[12] Donas J., Deharveng J. M., Laget M., Milliard B., Huguenin D., 1987, "Ultraviolet observations and star-formation rate in galaxies", Astronomy and Astrophysics, 180, 12-26.

[13] Schwarzschild M., 1959, "Photographs of the Solar Granulation Taken from the Stratosphere", The Astrophysical Journal, 130, 345.

[14] Hansen C. J., Esposito L. W., Aye K. M., Colwell J. E., Hendrix A. R., Portyankina G., Shemansky D., 2017, "Investigation of diurnal variability of water vapor in Enceladus' plume by the Cassini ultraviolet imaging spectrograph", Geophysical Research Letters, 44(2), 672-677.

[15] Hansen C., Esposito L., Colwell J., Hendrix A., Portyankina G., 2017, "Enceladus Plume Morphology and Variability from UVIS Measurements", AAS/Division for Planetary Sciences Meeting Abstracts, Vol. 49.

[16] Teolis B. D., Perry M. E., Hansen C. J., Waite J. H., Porco C. C., Spencer J. R., Howett C. J., 2017, "Enceladus Plume Structure and Time Variability: Comparison of Cassini Observations”, Astrobiology, 17(9), 926-940.

[17] Hendrix A. R., Hansen C. J., Royer E. M., Cassidy T. A., Esposito L. W., Holsclaw G. M., 2017, "Enceladus: Using UV Data to Study Plume Fallout", Lunar and Planetary Science Conference, Vol. 48.

[18] Scipioni F., Schenk P., Tosi F., D'Aversa E., Clark R., Combe J. P., Dalle Ore C. M., 2017, "Deciphering sub-micron ice particles on Enceladus surface", Icarus, 290, 183-200.

[19] Khare B. N., Sagan C., 1979, "Organic dust synthesized in reducing environments by ultraviolet radiation or electric discharge”, Astrophysics and Space Science, 65(2), 309-312.

[20] Neish C. D., Somogyi Á., Smith M. A., 2010, “Titan's primordial soup: formation of amino acids via low-temperature hydrolysis of tholins”, Astrobiology, 10(3), 337-347.

[21] Zalewska N., Kotlarz J., Kacprzak M., Korniluk T., 2017, „Detekcja biomarkerów w pióropuszach gazowych za pomocą kamery wielospektralnej w projektowanej misji Enceladus Orbiter (NASA)" ("Detection of Biomarkers in Gas Plumes Using a Multi-Spectral Camera in the Proposed Enceladus Orbiter Mission (NASA)"). Pomiary Automatyka Robotyka, 21(3), $35-44$. 
[22] Huffman R. E., 1985, "Atmospheric emission and absorption of ultraviolet radiation", Handbook of Geophysics and the Space Environment, Chap. 22, Air Force Geophysics Laboratory, Air Force Systems Command, US Air Force, Springfield.

[23] Lutgens F. K., Tarbuck E. J., Tusa D., 1995, The atmosphere. Englewood Cliffs, NJ: Prentice-Hall.

[24] Enfield D. B., Smith P. J., 2017, “Climate”, from: https://www.britannica.com/science/ climate-meteorology/Winds-in-the-stratosphere-and-mesosphere

[25] Hendrix A. R., Hansen C. J., Holsclaw G. M., 2010, “The ultraviolet reflectance of Enceladus: Implications for surface composition”, Icarus, 206(2), 608-617.

[26] Hendrix A. R., Hansen, C. J., 2009, "The surface composition of Enceladus: clues from the Ultraviolet”, Proceedings of the International Astronomical Union, 5(S263), 126-130.

[27] Farrell W. M., Wahlund J. E., Morooka M., Gurnett D. A., Kurth W. S., MacDowall R. J., 2012, "The electromagnetic pickup of submicron-sized dust above Enceladus's northern hemisphere", Icarus, 219(1), 498-501.

[28] Newman S. F., Buratti B. J., Jaumann R., Bauer J. M., Momary T. W., 2007, "Hydrogen peroxide on Enceladus", The Astrophysical Journal Letters, 670(2), L143.

\section{ANALIZA MOŻLIWOŚCI OBSERWACJI ENCELADUSA W ULTRAFIOLECIE ZA POMOCĄ BALONÓW STRATOSFERYCZNYCH}

\section{Streszczenie}

Balony stratosferyczne są bardzo ważnymi źródłami danych w badaniach kosmosu i obserwacji powierzchni Ziemi w wielu dyscyplinach naukowych. Instrumenty opracowane do pomiarów astrofizycznych są zwykle wielokrotnego użycia. Za pomocą balonów możliwe jest również obserwowanie obu półkul nieba, w tym obserwacji z regionów polarnych i równikowych przez trzydzieści dni lub nawet dłużej. Z drugiej strony okno transmitancji atmosferycznej UV było wykorzystywane w obserwacjach astrofizycznych rzadziej niż pasma optyczne z zakresu widzialnego. Pod koniec 2017 r. istnieje kilka grup naukowych zajmujących się budową spektrografów czułych na promieniowanie UV lub bliskie UV możliwych do montażu na balonach stratosferycznych.

W niniejszym artykule omawiamy możliwość pomiaru współczynnika odbicia powierzchniowego Enceladusa, lodowego księżyca Saturna, w paśmie UV między 200 a 400 nm z wysokości 20-50km. W pasmach widzialnym i bliskiej podczerwieni reflektancja Enceladusa jest bardzo wysoka (blisko 1,0). Wartość ta jest zgodna z modelami reflektancji powierzchni składającej się z lodu wodnego, jednak w niektórych pasmach UV współczynnik odbicia Enceladusa jest niższy, niż można się było spodziewać w przypadku tego typu powierzchni. Badania naukowe przeprowadzone w ostatnim dziesięcioleciu koncentrowały się na detekcji cząsteczek $\mathrm{H}_{2} \mathrm{O}, \mathrm{NH}_{3}$ i tiolin na powierzchni tego księżyca. Ciągła obserwacja zmienności współczynnika odbicia promieniowania w paśmie UV za pomocą balonów stratosferycznych może być interesująca i może dać nam dowód na obecność biomarkerów i / lub cząstek tiolin na powierzchni Enceladusa.

Słowa kluczowe: balony stratosferyczne, Enceladus, ultrafiolet, lód wodny, tioliny. 